\title{
FAKTOR-FAKTOR PENENTU TINGKAT TABUNGAN DI INDONESIA: PENDEKATAN MODEL LIFE CYCLE HYPOTHESIS
}

\author{
Arintoko \\ Universitas Jenderal Soedirman \\ e-mail: arintokoz@yahoo.co.id
}

\begin{abstract}
ABSTRAK
This study estimates a number of variables hypothesized affect saving rate in Indonesia. These variables such as growth of real income per capita, dependency ratio, interest rate, inflation and lag of saving rate are likely to exert influence on saving rate as suggested by theory and/or prior empirical work. This research employs regression model on time-series data. Research model is based on life cycle hypothesis. It is used to show effect of income growth and population structure on saving rate. Three of five variables used in the model significanly affect saving rate i.e.: real GDP per capita, inflation and lag of saving rate. These variables have positif effect on saving rate. Increasing GDP per capita has impact on increasing national saving rate. Increasing inflation indicates increasing uncertainty motivating households to raise their saving. In addition, there is an inertia of saving rate habit implying that national saving rate in Indonesia would be to exhibit cycle. Thus, saving rate would be increase in the future if there is upward trend in prior time.
\end{abstract}

Keywords: saving rate, life cycle hypothesis, income growth, population structure

\begin{abstract}
PENDAHULUAN
Indonesia merupakan negara berpenduduk besar yang dalam sejarah pertumbuhan ekonomi pernah mengalami keajaiban pada era 1990an. Ketika itu Indonesia menjadi salah satu dari delapan negara yang merupakan bagian dari keajaiban di Asia Timur. Keajaiban di Asia Timur menempatkan Indonesia sebagai negara industri baru masuk dalam kelompok delapan negara yang berprestasi tinggi dalam perekonomiannya (high-performing East Asian economies, HPAEs) di samping Jepang, empat macan Asia (Hongkong, Republik Korea, Singapura dan Taiwan), serta Malaysia dan Thailand sebagai negara industri baru lainnya (Word Bank, 1993).
\end{abstract}

Namun krisis ekonomi yang melanda Indonesia pada pertengahan tahun 1997 lalu membuat prestasi tersebut menjadi tidak berarti apa-apa. Perekonomian pada masa orde baru yang dibangun atas dasar prinsip lebih besar pasak daripada tiang ditandai dengan kesenjangan investasi tabungan yang semakin besar (Basri, 2002). Laju investasi yang meningkat karena optimisme yang berlebihan tidak dibarengi dengan peningkatan tabungan. Di sisi lain neraca transaksi berjalan Indonesia yang selalu mengalami defisit terutama pada era 1990-an dan defisit yang semakin bertambah sampai menjelang krisis membuat kondisi yang kurang menguntungkan bagi perekonomian Indonesia. Terlebih lagi ketika iklim investasi di Indonesia tidak terlalu menarik bagi investor 
asing untuk memasuki Indonesia. Kondisi tersebut memberikan andil yang cukup berarti pada semakin tergantungnya Indonesia pada hutang luar negeri (Tambunan, 2001). Faktor-faktor tersebut di dalam literatur memang sebagai penyebab membengkaknya hutang luar negeri negaranegara berkembang termasuk Indonesia.

Pada negara yang sedang membangun seperti Indonesia, keinginan untuk investasi dalam pembangunan ini biasanya besar karena besarnya sasaran yang ingin dicapai. Bahkan seringkali keinginan membangun suatu negara lebih besar dari kemampuan untuk membiayainya. Ekonom mengatakan bahwa negara yang sedang membangun biasanya menghadapi suatu kesenjangan antara investasi dengan tabungan masyarakat (investment-saving gap).

Suatu negara dapat membiayai kesenjangan ini dengan mendatangkan modal langsung dari luar negeri, dengan meminta bantuan dan mencari pinjaman dari negara lain. Meminjam dari masyarakat lain sama dengan menggunakan tabungan masyarakat lain tersebut. Membiayai kesenjangan antara investasi dan tabungan dengan pinjaman adalah sesuatu yang wajar. Namun tindakan meminjam dari negara lain atau masyarakat lain itu juga mempunyai konsekuensi tersendiri, karena pinjaman itu pada waktunya harus dibayar kembali, ditambah suatu imbalan atas penggunaan tabungan tersebut yang dinamakan bunga. Konsekuensi inilah yang kemudian ditanggung ketika Indonesia menjadi negara yang memiliki hutang luar negeri yang besar. Karena beban pengembalian hutang luar negeri ini pun pernah nyaris membuat Indonesia bangkrut secara finansial pada saat krisis ekonomi yang lalu. Jadi kalau menggunakan pinjaman atau hutang untuk membiayai kekurangan tabungan di dalam negeri dari biaya investasi, harus dipikirkan bagaimana melakukan pembayaran kembali pinjaman tersebut, berupa angsuran dan bunganya, serta resiko berkaitan dengan perbedaan waktu meminjam dan mengembalikan pinjaman tersebut.

Di tengah serangkaian pemikiran dan perdebatan tentang penolakan mengenai ketergantungan terhadap hutang luar negeri dengan segala dampak negatifnya, maka sumber pembiayaan domestik menjadi isu yang menarik untuk diteliti. Jika dibandingkan dengan sumber eksternal dalam pembiayaan pembangunan, menggantungkan harapan pada sumber-sumber domestik memang relatif lebih aman dan resikonya juga relatif kecil terhadap gejolak perekonomian global. Terlebih lagi dalam beberapa dekade terakhir, penerimaan minyak dan gas semakin tidak dapat diandalkan dalam membiayai pembangunan, sehingga mendorong perlunya alternatif penggalian dana domestik. Sumber pembiayaan dalam negeri dapat berasal dari tabungan masyarakat, tabungan pemerintah, penerimaan pajak, dan investasi swasta. Tabungan masyarakat yang termobilisasi melalui perbankan dan lembaga keuangan bukan bank dapat digunakan untuk membiayai investasi oleh pihak swasta. Mobilisasi dana ini sangat penting, khususnya dalam suatu negara yang menghadapi masalah tingginya kesenjangan antara investasi dan tabungan tak terkecuali Indonesia.

Dari uraian sebelumnya dapat disimpulkan bahwa ketergantungan pembiyaaan pembangunan terhadap hutang luar negeri justru membebani negara dan mendatangkan resiko yang besar, sementara defisitnya neraca transaksi berjalan dan kurang menariknya investor asing masuk ke dalam negeri akan memperparah keadaan perekonomian nasional. Selain itu, sumber pembiayaan pembangunan dari tabungan pemerintah yang semakin terbatas karena penerimaan minyak dan gas tidak dapat diandalkan lagi, maka dipandang penting menggantungkan harapan pada sumber pembiayaan domestik yang berasal dari tabungan masyarakat di dalam negeri. Hal ini mengingat bahwa Indonesia merupakan negara berpenduduk 
besar dan memiliki tingkat petumbuhan ekonomi yang relatif tinggi. Jadi, penting untuk mengetahui faktor-faktor penentu dan kecenderungan tingkat tabungan masyarakat di Indonesia melalui penelitian ini. Dengan diketahuinya faktor-faktor atau variabel-variabel yang berpengaruh secara empirik terhadap tabungan masyarakat di Indonesia, maka dimungkinkan untuk dapat meningkatkan tabungan domestik dengan mengoptimalkan faktor-faktor pendukungnya dan sebaliknya mengendalikan atau menekan faktor-faktor negatifnya, yang mungkin dilakukan terhadap keduanya dengan memperhatikan konsekuensi-konsekuensinya. Upaya ini akan mendorong peningkatan penyediaan dana yang memadai di dalam negeri untuk pembangunan atau membiayai kesenjangan investasi - tabungan tanpa harus bergantung pada hutang luar negeri.

Berdasarkan kesimpulan dari uraian mengenai pentingnya sumber pembiayaan dari tabungan masyarakat ketika tabungan pemerintah semakin terbatas, maka penting untuk mengetahui faktorfaktor apa yang menentukan tingkat tabungan masyarakat tersebut. Oleh karena itu permasalahan yang menjadi perhatian dalam penelitian ini yaitu variabel-variabel apa saja yang signifikan menentukan tingkat tabungan masyarakat di Indonesia dan berapa besar pengaruhnya serta bagaimana kecenderungan tingkat tabungan tersebut. Penelitian yang dilakukan ini didasarkan pada model hipotesis daur hidup (life cycle hypothesis) dengan beberapa asumsi seperti disampaikan dalam model teoritik di bagian selanjutnya.

Penelitian ini bertujuan untuk mengestimasi variabel-variabel yang diduga berpengaruh terhadap tingkat tabungan masyarakat di Indonesia yaitu pertumbuhan pendapatan per kapita riil, angka beban ketergantungan penduduk usia muda maupun penduduk usia tua, tingkat bunga, inflasi dan variabel lag dari tabungan masyarakat, serta bagaimana kecenderungannya.

\section{REVIEW LITERATUR DAN HIPOTESIS}

\section{Landasan Teoritik}

Model penelitian ini didasarkan pada hipotesis daur hidup dan penggunaan model ini untuk menunjukkan pengaruh pertumbuhan pendapatan dan struktur penduduk terhadap tingkat tabungan. Model ini juga digunakan untuk aplikasi penelitian di China oleh Horioka dan Wan (2006). Replikasi model penelitian di Indonesia dengan model yang diterapkan di China dengan mempertimbangkan bahwa Indonesia merupakan negara dengan jumlah penduduk yang besar dan memiliki tingkat pertumbuhan ekonomi yang relatif tinggi yang karakteristiknya mirip dengan China dalam hal ini.

Dengan horizon waktu yang dimulai dari 0 sampai $\mathrm{T}$, perekonomian dimulai dari waktu 0 . Pada waktu $0, \mathrm{n}^{0}(=1)$ orang dengan endowment berupa sumberdaya kapital manusia $\mathrm{y}^{0}(=1)$ masuk dalam perekonomian, dan pada waktu 1 , mereka menjadi tua dan meninggal. Orang-orang tersebut tidak memperoleh pendapatan pada waktu 1, tetapi mereka melakukan konsumsi baik pada waktu 0 maupun waktu 1 , yang berarti mereka menabung pada waktu 0 untuk membiayai konsumsi mereka pada waktu 1 . Variabel n dan y masing-masing menunjukkan pertumbuhan populasi dan pertumbuhan pendapatan. Selanjutnya pada periode $\mathrm{t}$, sebanyak $\mathrm{n}^{\mathrm{t}}$ orang baru masuk ke dalam perekonomian dengan endowment sebanyak $n^{t} y^{t}$ dan hidup bersama dengan $\mathrm{n}^{\mathrm{t}-1}$ orang yang sudah tua. Diasumsikan juga bahwa masyarakat tidak memiliki warisan dan bahwa sebanyak $\mathrm{n}^{t}$ orang baru tersebut tidak dapat meminjamkan kepada atau meminjam dari $\mathrm{n}^{\mathrm{t}-1}$ orang yang sudah tua. Semua orang diasumsikan homogen dan mempunyai fungsí utiliti log linear dengan kemungkinan adanya habits dan durability dalam perilaku konsumsi. Secara sederhana, tingkat preferensi waktu dan tingkat bunga diasumsikan nol. Jadi, 
bagi generasi baru dalam memecahkan masalah maksimisasi individu pada waktu $t$ adalah sebagai berikut :

$$
\begin{aligned}
& \text { Max } \log \left(c_{t}\right)+\log \left(c_{t+1}-\gamma c_{t}\right) \\
& \text { dengan kendala }: c_{t}+c_{t+1}=y^{t}
\end{aligned}
$$

dimana $c_{t}, c_{t+1}$ masing-masing menunjukkan konsumsi pada waktu $t$ dan waktu $t+1$. Sedangkan $\gamma$ merupakan parameter yang menunjukkan tingkat durability atau habits. Nilai $\gamma$ negatif mengindikasikan adanya durability, nilai positif mengindikasikan adanya habits, dan nilai nol mengindikasikan tidak adanya durability maupun habits dalam perilaku konsumsi. Diasumsikan juga bahwa $\gamma>-0,5$ dalam pengertian untuk meyakinkan bahwa $c_{t}>0, c_{t+1}>0$, dan $c_{t+1}-\gamma c_{t}>0$. Dengan asumsi-asumsi tertentu ini, penyelesaian persoalan untuk konsumsi pada waktu $t$ dan waktu $\mathrm{t}+1$ adalah :

$$
\begin{aligned}
& c_{t}=\frac{y^{t}}{2+2 \mathrm{~g}} \\
& c_{t+1}=\frac{(1+2 \mathrm{~g}) y^{t}}{2+2 \mathrm{~g}}
\end{aligned}
$$

Selanjutnya, tingkat tabungan agregat dapat diturunkan (dalam perekonomian) pada waktu $t$ $(\mathrm{t}>0)$ menjadi :

$$
\begin{aligned}
& S R=\frac{n^{t} y^{t}-\left\{n^{t} \frac{y}{2+2 \gamma}+n^{t-1} \frac{(1+2 \gamma) y^{t-1}}{2+2 \gamma}\right\}}{n^{t} y^{t}} \\
& S R=\frac{1+2 \gamma}{2+2 \gamma}\left\{1-\frac{1}{n y}\right\}
\end{aligned}
$$

Pengaruh dari $\mathrm{y}, \mathrm{n}$ dan $\gamma$ terhadap tingkat tabungan agregat adalah sebagai berikut :

$$
\begin{gathered}
\frac{\partial S R}{\partial y}=\frac{1+2 \gamma}{(2+2 \gamma) n y^{2}}>0, \\
\frac{\partial S R}{\partial n}=\frac{1+2 \gamma}{(2+2 \gamma) n^{2} y}>0,
\end{gathered}
$$

$$
\begin{aligned}
& \frac{\partial S R}{\partial \gamma}=\frac{n y-1}{2(1+\gamma)^{2} n y}>0 \quad \text { untuk } \quad \text { ny }>1, \\
& \frac{\partial S R}{\partial \gamma}=\frac{n y-1}{2(1+\gamma)^{2} n y}=0 \quad \text { untuk } \quad n y=1, \\
& \frac{\partial S R}{\partial \gamma}=\frac{n y-1}{2(1+\gamma)^{2} n y}<0 \quad \text { untuk } \quad \text { ny }<1 .
\end{aligned}
$$

Hasil ini mengimplikasikan bahwa pertumbuhan pendapatan dan kenaikan umur bekerja penduduk akan meningkatkan tingkat tabungan, serta bahwa penguatan dalam habits dan pelemahan dalam durability akan meningkatkan tingkat tabungan dalam perekonomian yang sedang mengalami booming, dan sebaliknya menurunkan tingkat tabungan dalam perekonomian yang sedang mengalami kelesuan. Model ini tepat untuk diaplikasikan pada penelitian yang akan dilakukan untuk suatu perekonomian dengan skala nasional (agregat) dalam periode waktu yang lebih panjang (runtut waktu tahunan selama kurang lebih dari 25 tahun) sebagaimana penelitian yang akan dilakukan ini.

\section{Tinjauan Empirik}

Hipotesis Keynes (1953) menyatakan bahwa tingkat pendapatan nasional berpengaruh positif terhadap tabungan rumah tangga. Hipotesis ini didukung oleh beberapa studi empirik antara lain dari Rossi (1988), Modigliani dan Cao (2004), serta Horioka dan Wan (2006).

Selain itu menurut Keynes tingkat bunga juga berpengaruh positif terhadap tingkat tabungan. Pandangan ini didukung oleh beberapa studi empirik di antaranya Arrieta (1988), Muradoglu dan Taskin (1996), serta Horioka dan Wan (2006).

Beberapa variabel yang berkaitan dengan struktur populasi, studi Leff (1969) menemukan bukti empirik bahwa beban tanggungan secara signifikan mempengaruhi tabungan agregat. 
Bukti empirik ini juga ditemukan Loayza et al. (2000), Modigliani dan Cao (2004) dalam penelitiannya di China. Namun hasil berbeda disampaikan oleh Ram (1982), Kraay (2000), serta Horioka dan Wan (2006) yang tidak menemukan adanya pengaruh signifikan struktur populasi terhadap tingkat tabungan masyarakat.

Berkaitan dengan variabel inflasi, terdapat perbedaan pendapat berdasarkan studi empirik mengenai efek inflasi terhadap tabungan di negara sedang berkembang. Juster dan Wachtel (1972) sebagaimana dikutip oleh Lahiri (1989) menemukan bahwa inflasi akan mengurangi kepastian konsumen dan akhirnya akan meningkatkan tabungan. Pandangan ini didukung oleh Deaton (1977), Gupta (1987), serta Skinner (1988) dan Zeldes (1989) dalam Loayza et al. (2000) yang menyatakan bahwa ketidakpastian yang lebih besar di masa datang akan meningkatkan tabungan. Penelitian Bovenberg dan Evans (1990) juga menemukan bukti yang sama di Amerika Serikat. Lebih dari itu dalam penelitian terbaru Modigliani dan Cao (2004), serta Horioka dan Wan (2006) dalam beberapa kasus sampel rumah tangga di China juga menemukan bukti yang sama. Namun demikian kebalikan dari temuan Branson dan Klevorick (1969) menemukan fakta adanya dampak negatif dari inflasi terhadap tabungan di Amerika Serikat. Selain itu juga studi empiriknya Kauffmann dalam Muradoglu dan Taskin (1996) yang juga di Amerika Serikat, serta Howard (1978) pada penelitiannya di Jepang.

Beberapa studi empirik relatif baru berkaitan dengan tabungan rumah tangga yang dilakukan di China antara lain oleh Kraay (2000), Modigliani dan Cao (2004), serta Horioka dan Wan (2006) juga menemukan bukti empirik yang mendukung hasil-hasil penelitian sebelumnya. Kraay (2000) dengan menggunakan data panel propinsi di China menemukan hasil bahwa pertumbuhan pendapatan masa depan dan konsumsi total berpengaruh negatif dan signifikan terhadap tingkat tabungan. Sebaliknya variabel rasio ketergantungan tidak berpengaruh signifikan terhadap tingkat tabungan rumah tangga di China.

Selanjutnya Modigliani dan Cao (2004) yang menggunakan analisis regresi terhadap data runtut waktu periode 1953-2000, menemukan variabel tingkat pertumbuhan jangka panjang, rasio ketergantungan, deviasi pertumbuhan dalam jangka panjang, dan inflasi memiliki pengaruh positif dan signifikan terhadap tingkat tabungan rumah tangga di China. Sementara Horioka dan Wan (2006) dalam penelitiannya menemukan bahwa tingkat tabungan rumah tangga di China cukup tinggi dan meningkat, serta variabel-variabel penentu utama yaitu lag dari tingkat tabungan, tingkat pertumbuhan pendapatan signifikan, dan dalam beberapa kasus tingkat bunga dan inflasi juga signifikan mempengaruhi tingkat tabungan. Penelitian mengenai tingkat tabungan ini dilakukan terhadap data panel propinsi di China selama periode 1995 - 2004 dan modelnya didasarkan pada hipotesis daur hidup. Variabelvariabel yang berhubungan dengan struktur umur populasi ternyata tidak signifikan mempengaruhi tingkat tabungan. Namun demikian hasil ini tetap mendukung hipotesis daur hidup. Hasil ini juga konsisten dengan adanya sifat inersia atau kelembaman dan mengimplikasikan bahwa tingkat tabungan rumah tangga di China akan tetap tinggi di masa datang.

Dalam studi empirik di Indonesia mengenai tabungan masyarakat, Darmawan (2006) menemukan hasil yang menunjukkan bahwa tingkat pendapatan masyarakat berdampak positif terhadap tingkat tabungan di seluruh wilayah di Indonesia. Tingkat suku bunga deposito riil tahunan ditemukan mempunyai dampak positif terhadap tabungan masyarakat antar daerah di Indonesia. Sementara itu faktor demografi yang diwakili oleh 
beban tanggungan memberikan pengaruh negatif terhadap tabungan hanya pada beban tanggungan usia muda. Selain itu faktor ketidakpastian yang diproksi dengan laju inflasi ternyata mempunyai dampak positif di beberapa daerah. Secara keseluruhan hasil penelitian ini menunjukkan terjadinya variasi antara faktor-faktor yang mempengaruhi tabungan masyarakat antar daerah di Indonesia yang merupakan bukti bahwa terdapat perbedaan perilaku tabungan masyarakat antar daerah.

Selanjutnya penelitian yang akan dilakukan ini mencoba mengaplikasikan model yang digunakan Horioka dan Wan (2006) yang telah menyempurnakan model penelitian-penelitian sebelumnya di China, namun diaplikasikan untuk tingkat tabungan agregat (nasional) di Indonesia yang memiliki karakteristik yang hampir sama dengan China dalam hal pertumbuhan ekonomi yang relatif tinggi dan struktur penduduknya. Penelitian ini menggunakan data runtut waktu tahunan selama kurun waktu 25 tahun sehingga meskipun modelnya sama namun berbeda dalam penggunaan data, dimana data yang digunakan Horioka dan Wan (2006) adalah data panel propinsi. Selain itu ada perbedaan dalam pengukuran variabel tingkat tabungan dimana dalam penelitian ini tingkat tabungan masyarakat diukur dengan jumlah dana simpanan rupiah dan valuta asing pada bank umum untuk jenis tabungan dan deposito, sementara pada penelitian Horioka dan Wan (2006) diukur dengan tingkat tabungan rumah tangga (pendapatan siap pakai dikurangi konsumsi). Penelitian ini juga berbeda dengan Darmawan (2006) dalam hal model maupun datanya karena penelitiannya juga menggunakan data panel antar propinsi.

\section{METODE PENELITIAN}

Berdasarkan landasan teori, tinjauan hasil penelitian dan hipotesis yang diajukan maka dapat dibentuk model dasar sebagai berikut :

$\mathrm{SR}=\mathrm{f}($ INDY, YOUNG, OLD, DEP, RINT,

INFL, SR(-1))

dimana:

$\mathrm{SR}=$ tabungan masyarakat

INDY $=$ GDP per kapita riil

YOUNG $=$ angka beban ketergantungan penduduk usia muda

$\mathrm{OLD}=$ angka beban ketergantungan penduduk usia tua

$\mathrm{DEP}=$ angka beban ketergantungan total

RINT $=$ tingkat bunga

INFL $=$ inflasi

$\mathrm{SR}(-1)=$ variabel lag satu tahun dari tabungan masyarakat

Dari model dasar tersebut selanjutnya dapat disajikan bentuk persamaan regresinya sebagai berikut :

$$
\mathrm{SR}=\alpha+\beta_{1} \mathrm{INDY}+\beta_{2} \mathrm{YOUNG}+\beta_{3} \mathrm{OLD}+
$$
$\beta_{4} \mathrm{DEP}+\beta_{5} \mathrm{RINT}+\beta_{6} \mathrm{INFL}+\beta_{7} \mathrm{SR}(-1)+\varepsilon$

$\beta_{1}, \beta_{2}, \beta_{3}, \beta_{4}, \beta_{5}, \beta_{6}, \beta_{7}$ merupakan parameter dari masing-masing variabel bebas yang akan diuji secara statistik dengan uji $\mathrm{t}$ berkaitan dengan hipotesis yang disampaikan dan $\varepsilon$ merupakan error term. Selain itu uji F akan dilakukan untuk menguji signifikansi variabel-variabel penjelas tersebut terhadap variabel terikat secara bersamasama (simultan) dalam model.

\section{Variabel dan Data}

Penelitian ini menggunakan analisis regresi yang dilakukan dengan menggunakan data runtut waktu (time-series) tahunan secara nasional selama periode 1983 - 2007. Tahun awal yang digunakan adalah 1983 dengan alasan bahwa tahun tersebut merupakan awal berkembangnya 
kegiatan perbankan dalam menghimpun dana dari masyarakat setelah ada kebijakan pemerintah berupa Paket Juni 1983 atau PAKJUN 83. Data dikumpulkan dari publikasi Badan Pusat Statistik (BPS), Bank Indonesia, dan Departemen Keuangan Republik Indonesia. Variabel yang digunakan dalam penelitian ini dapat didefinisikan sebagai berikut:

(1) Tabungan masyarakat (SR) merupakan jumlah dana simpanan rupiah dan valuta asing dari jenis tabungan dan deposito pada bank umum.

(2) GDP per kapita riil (INDY) merupakan produk domestik bruto riil dengan tahun dasar 2000 yang dibagi jumlah populasi.

(3) Angka beban ketergantungan muda (YOUNG) merupakan rasio jumlah penduduk umur 0 - 14 terhadap jumlah penduduk umur $15-64$.

(4) Angka beban ketergantungan tua (OLD) merupakan rasio jumlah penduduk umur 65 keatas terhadap jumlah penduduk umur $15-64$.

(5) Angka beban ketergantungan total (DEP) merupakan rasio jumlah penduduk umur 0 - 14 dan 65 keatas terhadap jumlah penduduk umur $15-64$.

(6) Tingkat bunga (RINT) merupakan tingkat bunga nominal. Sebagai pendekatan tingkat bunga nominal maka tingkat bunga nominal yang digunakan adalah tingkat bunga deposito satu tahun.

(7) Inflasi (INFL) diukur dengan perubahan (dalam persentase) indeks harga konsumen.

(8) Variabel lag satu tahun dari tabungan masyarakat atau SR(-1) digunakan karena mempertimbangkan adanya sifat inersia atau kelembaman.
Dari model persamaan regresi yang dies-timasi dalam penelitian ini akan dilaporkan hasil estimasi parameter beserta angka-angka $R^{2}$, t statistik, F statistik yang disebut goodness of fit, serta uji asumsi klasik. Uji asumsi klasik meliputi uji multikolinearitas, heteroskedastisitas dengan uji Park dan Glejser, uji autokorelasi dengan uji $d$ dan $h$ Durbin-Watson.

\section{HASIL PENELITIAN DAN PEMBAHASAN}

\section{Perkembangan Tabungan dan Deposito}

Tabungan dan deposito merupakan bagian dari dana pihak ketiga di perbankan yang lebih mencerminkan kepemilikan individu dari masyarakat dibandingkan bentuk giro. Oleh karena itu variabel ini digunakan sebagai indikator tingkat tabungan masyarakat di Indonesia dalam penelitian ini.

Reformasi perbankan di Indonesia mulai dilakukan sejak tahun 1983 dengan tujuan utama untuk mengurangi campur tangan pemerintah yang terlalu besar agar mendorong tumbuhnya perekonomian serta memperbaiki dan meningkatkan kemampuan bank-bank umum dalam memobilisasi dana dari masyarakat. Memburuknya kondisi perekonomian pada tahun 1980-an yang ditandai dengan anjloknya harga minyak internasional menyebabkan turunnya penerimaan pemerintah dan pertumbuhan ekonomi yang cukup signifikan. Kondisi tersebut mendorong upaya pemerintah untuk lebih meningkatkan peran perbankan dalam perekonomian. Sampai tahun 1983 Bank Indonesia masih menerapkan pembatasan kredit dan pengaturan tingkat bunga. Bank Indonesia juga menyediakan kredit likuiditas kepada bank-bank umum untuk meningkatkan jumlah kreditnya yang diberikan kepada dunia usaha. 


\section{Gambar 1}

\section{Perkembangan Jumlah Tabungan dan \\ Deposito, serta Dana Pihak Ketiga \\ Perbankan, 1983 - 2007}

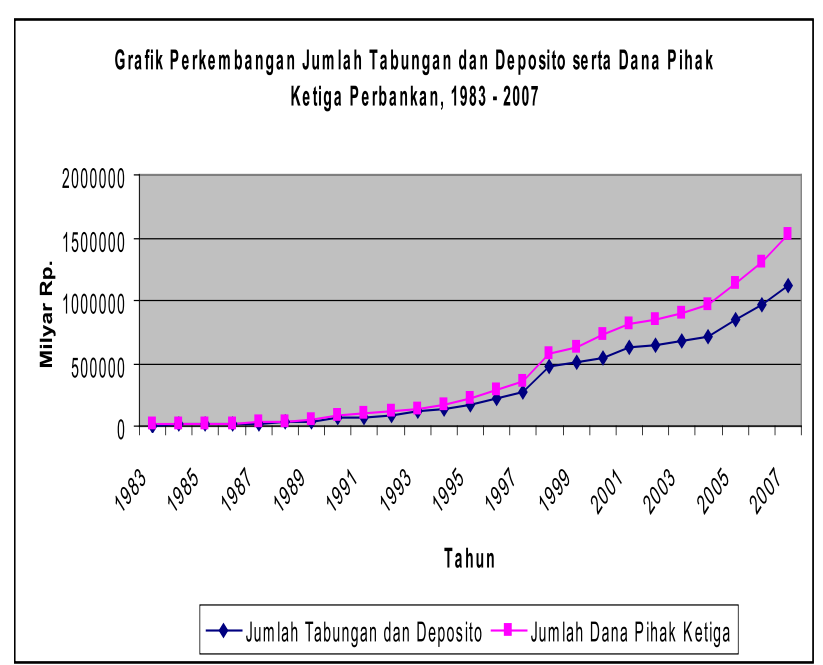

Sumber: Bank Indonesia, diolah.

Grafik pada gambar 1 menunjukkan bahwa sejak tahun 1983 jumlah tabungan dan deposito masyarakat Indonesia meningkat secara terus menerus dan mulai tahun 1990-an jumlah tersebut meningkat cukup pesat sampai dengan menjelang krisis ekonomi tahun 1997. Sejak diberlakukannya serangkaian paket kebijkasanaan yang yang disebut dengan PAKTO 88 industri perbankan berkembang dengan pesat karena deregulasi ini telah memberikan peluang kepada bank-bank baru untuk memasuki industri serta kelonggaran untuk mendirikan cabang-cabang baru. Dalam rangka untuk mengurangi ketergantungan bank umum kepada Bank Indonesia atas kredit likuiditas, maka dengan paket kebijakan ini pemerintah menghapuskan pembatasan pinjaman antar bank, menurunkan cadangan wajib minimum dari 5 - 15 persen menjadi 2 persen dari kewajiban terhadap pihak ketiga. Kondisi seperti ini selanjutnya akan menciptakan persaingan dalam industri perbankan. Dengan pertumbuhan jumlah dan kantor bank semenjak deregulasi ini telah mendorong bank-bank lebih agresif dalam menghimpun dana dari pihak ketiga melalui berbagai penawaran yang menarik dalam rangka menghimpun baik giro, deposito maupun tabungan dari masyarakat.

\section{Gambar 2}

\section{Perkembangan Rasio Jumlah Tabungan dan Deposito Terhadap Dana Pihak Ketiga Perbankan, 1983 - 2007}

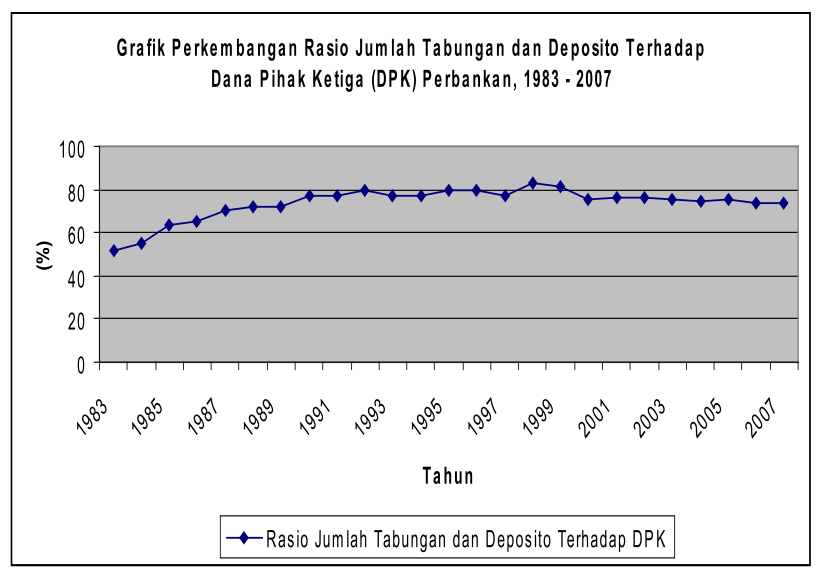

Sumber: Bank Indonesia, diolah.

Grafik pada gambar 2 menunjukkan bahwa jumlah tabungan dan deposito semakin memberikan kontribusi yang besar dalam penghimpunan dana di perbankan yang selanjutnya digunakan untuk pembiayaan investasi dalam pembangunan. Pada tahun 1983 kontribusi tabungan dan deposito dalam dana pihak ketiga masih seki$\operatorname{tar} 51 \%$. Namun kontribusi tersebut sejak tahun 1983 meningkat terus memasuki tahun 1990-an tepatnya tahun 1992 kontribusi tersebut mencapai $79 \%$ sebelum menurun kembali namun dalam angka yang kecil. Namun selanjutnya kontribusi tersebut meningkat lagi dan puncaknya terjadi pada tahun 1998 dengan kontribusi sebesar 83\%. Secara keseluruhan terdapat peningkatan kontribusi jumlah tabungan dan deposito terhadap dana pihak ketiga yang dihimpun perbankan selama tahun 1983 - 2007 dari sekitar 51\% menjadi 73\% pada tahun 2007. 
Dilihat dari pertumbuhannya kegiatan penghimpunan dana dan penyaluran kredit oleh perbankan sampai dengan pertengahan tahun 1997 secara umum masih berkembang dengan kecepatan tinggi. Mobilisasi dana masyarakat meningkat pesat sementara ekspansi kredit tetap kuat.

Setelah krisis ekonomi lambatnya proses pemulihan fungsi intermediasi perbankan disebabkan juga karena beberapa hambatan seperti masih tingginya persepsi perbankan terhadap risiko dan ketidakpastian di sektor riil. Kondisi tersebut menyebabkan perbankan berhati-hati dalam menyalurkan kredit, terutama kredit kepada sektor korporat dan kredit yang berjangka panjang. Namun demikian kegiatan penghimpunan dana tetap tinggi dan ada kecenderungan meningkat pesat sejak tahun 1999 sebagaimana terlihat pada grafik di gambar 1 sebelumnya.

Beberapa tahun setelah terjadinya krisis bankbank memiliki selisih yang sangat besar antara dana pihak ketiga dengan kredit. Kelebihan dana ini oleh perbankan cenderung ditempatkan dalam SBI maupun Pasar Uang Antar Bank (PUAB) mengingat tingginya suku bunga pinjaman juga sektor riil yang dipandang mengandung risiko kredit lebih tinggi sejalan dengan belum kondusifnya iklim usaha di Indonesia saat itu terkait dengan country risk yang tinggi.

\section{Hasil Penelitian}

Pada bagian awal disajikan hasil regresi dengan bentuk model berikut ini. Berdasarkan landasan teori, tinjauan hasil penelitian dan hipotesis yang diajukan maka estimasi model pada penelitian ini didasarkan pada persamaan (8). Hasil regresi dengan model tersebut selanjutnya disajikan pada tabel 1 berikut :
Tabel 1

Hasil Regresi Model Awal yang Digunakan

\begin{tabular}{|c|c|c|c|c|}
\hline Variabel & Koefisien & t Statistik & Prob. & Keterangan \\
\hline Konstanta & $-13,2415$ & $-2,5199$ & 0,0220 & $\begin{array}{l}\text { Signifikan } \\
\text { pada } \alpha= \\
0,05\end{array}$ \\
\hline INDY & 0,6682 & 2,5744 & 0,0197 & \\
\hline YOUNG & $-0,1059$ & $-0,5438$ & 0,5936 & \\
\hline OLD & 0,6583 & 1,8230 & 0,0859 & \\
\hline DEP & 0,1226 & 0,6248 & 0,5404 & \\
\hline RINT & 0,0121 & 1,6476 & 0,1178 & \\
\hline INFL & 0,0044 & 2,6954 & 0,0153 & $\begin{array}{c}\text { pada } \alpha= \\
0,05\end{array}$ \\
\hline $\operatorname{SR}(-1)$ & 0,7053 & 9,0463 & 0,0000 & $\begin{array}{c}\text { Signifikan } \\
\text { pada } \alpha= \\
0.05\end{array}$ \\
\hline \multicolumn{3}{|l|}{$\mathrm{R}^{2}=0,9985$} & \multirow{2}{*}{\multicolumn{2}{|c|}{$\begin{array}{c}\text { F-Ststistik }=1583,955 \\
\text { Prob }(\text { F-Ststistik })= \\
0,0000\end{array}$}} \\
\hline \multicolumn{3}{|c|}{ Durbin Watson Statistik $=2,5794$} & & \\
\hline
\end{tabular}

Tabel $1 \mathrm{di}$ atas menampilkan parameter atau koefisien dari masing-masing variabel independen berserta $t$ statistik dan signifikansinya. Sebelum sampai pada pengujian statistik lebih lanjut, pada langkah awal dapat dikatakan bahwa dari tabel ditunjukkan adanya tiga variabel yaitu GDP per kapita riil (INDY), inflasi (INFL) dan lag tabungan (SR(-1)) yang signifikan pada tingkat kepercayaan $95 \%$ atau $\alpha=0,05$. Namun demikian setelah dilakukan investigasi secara statistik ternyata terdapat indikasi adanya kolinearitas antara variabel angka beban ketergantungan muda (YOUNG), angka beban ketergantungan tua (OLD) dan angka beban ketergantungan total 
(DEP). Hasil investigasi statistik untuk indikasi kolinearitas antar variabel independen tersebut didasarkan pada $\mathrm{R}^{2}$ regresi antar variabel independen. Jika terdapat $\mathrm{R}^{2}$ dari regresi antar variabel independen memberikan $\mathrm{R}^{2}$ yang tinggi melebihi $\mathrm{R}^{2}$ dari regresi model utamanya maka menurut Klein's Rule of Thumb maka model tersebut terdapat multikolinearitas serius. Multikolinearitas yang terjadi akan menyebabkan parameter yang diestimasi menjadi tidak tepat. Hasil pengujian menunjukkan bahwa pada persamaan-persamaan regresi yang menempatkan salah satu dari tiga variabel yang disebutkan di atas sebagai variabel dependen dan minimal juga terdapat satu variabel tersebut ternyata menghasilkan $\mathrm{R}^{2}$ yang tinggi melebihi $\mathrm{R}^{2}$ regresi model utamanya.

Hasil uji menunjukkan bahwa persamaanpersamaan regresi yang terdapat salah satu variabel dari variabel YOUNG, OLD, maupun DEP sebagai variabel dependen dan minimal satu dari variabel tersebut sebagai variabel independen menghasilkan $\mathrm{R}^{2}$ yang tinggi melebihi $\mathrm{R}^{2}$ regresi model utamanya. Selanjutnya disimpulkan bahwa terdapat kolinearitas tinggi antar ketiga variabel tersebut yang menjadi dasar pertimbangan untuk mengelimiasi variabel YOUNG dan OLD dengan cukup menggunakan variabel DEP untuk mewakili angka ketergantungan sebagai veriabel yang diprediksi mempengaruhi tingkat tabungan.

Setelah melalui proses eliminasi dua variabel tersebut maka model baru yang diestimasi dalam penelitian ini menjadi :

$$
\begin{aligned}
& \mathrm{SR}=\alpha+\beta_{1} \mathrm{INDY}+\beta_{2} \mathrm{DEP}+\beta_{3} \mathrm{RINT}+\beta_{4} \mathrm{INFL} \\
& +\beta_{5} \mathrm{SR}(-1)+\varepsilon
\end{aligned}
$$

Tabel 2

Hasil Regresi Model Perbaikan

\begin{tabular}{|l|c|c|c|l|}
\hline \multicolumn{1}{|c|}{ Variabel } & Koefisien & $\begin{array}{c}\mathrm{t} \\
\text { Statistik }\end{array}$ & Prob. & Keterangan \\
\hline Konstanta & $-5,1498$ & $-1,2078$ & 0,2419 & $\begin{array}{l}\text { Signifikan } \\
\text { pada } \alpha=0,05\end{array}$ \\
INDY & 0,5726 & 2,0871 & 0,0506 & \\
DEP & $-0,0197$ & $-1,2401$ & 0,2300 & \\
RINT & 0,0087 & 1,1720 & 0,2557 & \\
INFL & 0,0046 & 2,6755 & 0,0150 & $\begin{array}{l}\text { Signifikan } \\
\text { pada } \alpha=0,05\end{array}$ \\
SR(-1) & 0,7810 & 10,2094 & 0,0000 & $\begin{array}{l}\text { Signifikan } \\
\text { pada } \alpha=0,05\end{array}$ \\
\hline \multicolumn{5}{|l}{} \\
$\mathrm{R}^{2}=0,9980$
\end{tabular}

Hasil regresi model perbaikan disajikan pada tabel 2 yang menunjukkan bahwa hasilnya tetap konsisten bahwa terdapat tiga variabel independen yaitu GDP per kapita riil (INDY), inflasi (INFL) dan lag tabungan (SR(-1)) yang signifikan pada tingkat kepercayaan $95 \%$ atau $\alpha=0,05$. Namun demikian terdapat kebaikan yang lain dari model ini yaitu F statistik yang lebih tinggi tanpa perubahan $\mathrm{R}^{2}$ yang berarti, serta dimungkinkan terbebas dari penyimpangan asumsi klasik sebagai syarat untuk mendapatkan parameter estimasi yang tepat.

Angka $\mathrm{R}^{2}$ hasil regresi dari model yang diestimasi ini adalah sebesar 0,9980 yang merupakan yang cukup tinggi untuk data runtut waktu. Arti dari angka tersebut bahwa 99,80 persen dari variasi tingkat tabungan selama periode penelitian dapat dijelaskan oleh variabel-variabel independen yang dipilih dalam model penelitian ini.

Angka adjusted $R^{2}$ tidak berubah ketika dilakukan pengeliminasian variabel YOUNG dan OLD dari model awal ke model baru untuk menghindari multikolinearitas pada model regresi. 
Nilai adjusted $R^{2}$ yang tidak berubah menunjukkan bahwa kedua variabel tersebut memang tidak begitu tepat dimasukkan ke dalam model sehingga model menjadi efisien.

Nilai F statitstik dari hasil regresi model yang diperoleh adalah 1881,197 . F statitstik signifikan pada $\alpha=0,05$. Uji $F$ berdasarkan hasil tersebut menarik kesimpulan bahwa hipotesis nol yang menyatakan bahwa seluruh variabel bebas secara simultan tidak berpengaruh terhadap tingkat tabungan masyarakat $\left(\beta_{1}=\beta_{2}=\beta_{3}=\beta_{4}=\beta_{5}=0\right)$, ditolak. Artinya seluruh variabel bebas dalam model secara simultan berpengaruh terhadap tingkat tabungan masyarakat.

Terkait dengan uji t dari lima variabel bebas terdapat tiga variabel yang signifikan pada $\alpha=$ 0,05 . Ketiga variabel tersebut adalah GDP per kapita riil (INDY), inflasi (INFL) dan lag tabungan (SR(-1)). Secara statistik variabel GDP per kapita riil, tingkat inflasi dan lag dari tingkat tabungan berpengaruh positif terhadap tingkat tabungan masyarakat pada $\alpha=0,05$.

Berkenaan dengan uji asumsi klasik hasil penelitian ini telah memenuhi asumsi klasik. Hasil investigasi statistik untuk indikasi kolinearitas antar variabel independen tersebut menunjukkan bahwa tidak terdapat $\mathrm{R}^{2}$ dari regresi antar variabel independen memberikan $\mathrm{R}^{2}$ yang tinggi yang melebihi $\mathrm{R}^{2}$ dari regresi model utamanya. Oleh karena itu menurut Klein's Rule of Thumb model ini tidak terdapat multikolinearitas yang serius sehingga parameter yang diestimasi dari hasil regresi ini dapat diterima.

Dari hasil investigasi melalui uji Park ${ }^{1}$ tidak ditemukan hubungan di antara variabel $\mathrm{X}_{\mathrm{i}}$ dan $\ln \varepsilon_{i}^{2}$ dengan indikasi tidak terdapat satupun pa-

$1 \quad$ Didasarkan pada persamaan $\ln \varepsilon_{\mathrm{i}}^{2}=\alpha_{1}+\alpha_{2} \ln \mathrm{X}_{\mathrm{i}}$ rameter variabel $\mathrm{X}_{\mathrm{i}}$ tersebut yang signifikan pada $\alpha=0,05$. Oleh karena itu disimpulkan bahwa hasil regresi dengan model yang diestimasi ini tidak terjadi heteroskedastisitas.

Sementara itu dari hasil investigasi melalui uji Geljser ${ }^{2}$ juga tidak ditemukan hubungan di antara variabel $X_{i}$ dan $\left|e_{i}\right|$ dengan indikasi tidak terdapat satupun parameter variabel $\mathrm{X}_{\mathrm{i}}$ tersebut yang signifikan pada $\alpha=0,05$. Oleh karena itu disimpulkan bahwa hasil regresi dengan model yang diestimasi ini tidak terjadi heteroskedastisitas. Hasil uji Glejser memperkuat hasil uji Park yang meyimpulkan bahwa hasil regresi model penelitian ini terbebas dari masalah heteroskedatisitas.

Hasil regresi memberikan statistik $d$ Durbin-Watson sebesar 2,434. Dengan N sebanyak 25 dan jumlah variabel bebas sebanyak 5 maka keputusan ada tidaknya autokorelasi. Berdasarkan nilai $d w$ statistik sebesar 2,434 maka $d w$ statistik tersebut terletak pada daerah keragu-raguan untuk keputusan ada tidaknya autokorelasi. $^{3}$ Namun demikian karena model regresi dalam penelitian ini merupakan model persamaan autoregresi yang menggunakan lag dari variabel dependennya maka uji ini menjadi tidak tepat. Uji yang tepat untuk regresi model persamaan autoregresi adalah uji $h$ statistik. Namun untuk melakukan uji $h$ statistik diperlukan nilai $d w$ statistik untuk menghitung $h$ statistiknya.

Uji $h$ statistik untuk model regresi dalam penelitian ini adalah didasarkan pada persamaan permintaan regresi :

$$
\mathrm{Y}_{\mathrm{t}}=\alpha_{0}+\alpha_{1} \mathrm{X}_{\mathrm{it}}+\alpha_{2} \mathrm{Y}_{\mathrm{t}-1}+u_{\mathrm{t}}
$$

2 Didasarkan pada persamaan $\left|\varepsilon_{\mathrm{i}}\right|=\alpha_{1}+\alpha_{2} \mathrm{X}_{\mathrm{i}}+$ $v_{\mathrm{i}}$. Jika koefisien dari $\mathrm{X}_{\mathrm{i}}$ maka terdapat hubungan di antara keduanya dan berarti pada model yang diestimasi terjadi heteroskedastisitas. 
dimana :

$\mathrm{Y}=$ tingkat tabungan

$\mathrm{X}_{\mathrm{i}}=$ variabel GDP per kapita riil (INDY), angka beban kertegantungan total (DEP), tingkat bunga (RINT), inflasi (INFL)

$\mathrm{Y}_{\mathrm{t}-1}=$ variabel lag tingkat tabungan

$$
h=\hat{r} \sqrt{\frac{n}{1-n\left[\operatorname{vara}_{2}\right]}} \text { dimana } \hat{r} \approx 1-\frac{d}{2}
$$

$\operatorname{vara}_{2}=$ varian dari parameter $\alpha_{2}$ yang diestimasi

$d=$ statistik $d$ Durbin-Watson dari hasil regresi model

Dari hasil perhitungan diperoleh nilai $\mathrm{h}$ statistik -1,174. Kesimpulannya, berkaitan dengan uji statistik $h$ karena nilai $h$ statistik terletak pada antara -3 dan +3 (Gujarati dan Porter, 2009), maka pengujian menolak hipotesis nol yang menyatakan tidak ada autokorelasi.

\section{Analisis Hasil Regresi}

Dari lima variabel bebas yang digunakan dalam model yang telah diperbaiki terdapat tiga variabel yang signifikan mempengaruhi tingkat tabungan, yaitu GDP per kapita riil, inflasi dan variabel lag dari tingkat tabungan dan ketiganya memiliki pengaruh positif. Variabel GDP per kapita riil berpengaruh positif terhadap tingkat tabungan masyarakat. Dalam kasus di Indonesia kecenderungan peningkatan GDP per kapita riil berpengaruh pada dengan kenaikan tingkat tabungan selama periode penelitian. Kenaikan GDP per kapita riil berdampak pada peningkatan tingkat tabungan masyarakat. Dengan marginal propensity to consume (MPC) tertentu, maka kenaikan GDP per kapita riil akan meningkatkan tabungan masyarakat. Dari hasil regresi dapat diintepretasikan bahwa kenaikan GDP per kapita riil sebesar $1 \%$ akan meningkatkan tabungan masyarakat sebesar $0,57 \%$.

Secara teoritik dan empirik keberadaan variabel GDP per kapita riil dalam mempengaruhi tingkat tabungan cukup kuat (robust) karena banyak terbukti dalam sejumlah studi empirik termasuk dalam penelitian ini. Hipotesis Keynes (1953) yang menyatakan bahwa tingkat pendapatan nasional berpengaruh positif terhadap tabungan rumah tangga didukung oleh beberapa studi empirik antara lain dari Rossi (1988), Modigliani dan Cao (2004), serta Horioka dan Wan (2006).

Dalam penelitian ini variabel inflasi juga berpengaruh positif terhadap tingkat tabungan. Inflasi yang meningkat mendorong masyarakat untuk meningkatkan tabungan. Meskipun parameter dari perubahan tabungan akibat perubahan inflasi adalah kecil untuk di Indonesia, namun pengaruhnya sangat signifikan. Temuan ini sependapat dengan argumetasi dari Juster dan Wachtel (1972) sebagaimana dikutip oleh Lahiri (1989) yang menemukan bahwa inflasi akan mengurangi kepastian konsumen dan akhirnya akan meningkatkan tabungan. Demikian pula terhadap pandangan yang didukung oleh Deaton (1977), Gupta (1987), serta Skinner (1988) dan Zeldes (1989) dalam Loayza et al. (2000) yang menyatakan bahwa ketidakpastian yang lebih besar di masa datang akan meningkatkan tabungan. Hasil penelitian ini juga sejalan dengan hasil penelitian Bovenberg dan Evans (1990) juga menemukan bukti yang sama di Amerika Serikat, Modigliani dan Cao (2004), serta Horioka dan Wan (2006) di China.

Variabel lag tingkat tabungan berpengaruh positif terhadap tingkat tabungan pada tahun 
tertentu. Hal ini menunjukkan adanya dorongan tingkat tabungan pada waktu sebelumnya terhadap tingkat tabungan sekarang yang berarti terdapat sifat inersia atau kelembaman pada tingkat tabungan. Hal ini mengimplikasikan bahwa tingkat tabungan masyarakat di Indonesia akan tetap meningkat di masa datang. Namun demikian kecenderungan naiknya tingkat tabungan di masa datang mungkin tidak bersifat persistent karena perilakunya tidak terlepas dari siklus bisnis.

Variabel angka beban ketergantungan tidak signifikan terhadap tingkat tabungan. Hasil penelitian ini sejalan dengan penelitian Horioka dan Wan (2006) yang menemukan bahwa variabelvariabel yang berhubungan dengan struktur umur populasi ternyata tidak signifikan mempengaruhi tingkat tabungan. Untuk kasus di Indonesia hal ini dapat dikemukakan bahwa masih ada faktor lain yang harus mendukung agar struktur umur produktif berpengaruh terhadap tingkat tabungan yaitu faktor tingkat kesempatan kerja yang tersedia bagi penduduk umur produktif. Tingkat kesempatan kerja yang terbatas mencerminkan bahwa tidak semua penduduk umur produktif memperoleh pekerjaan dan pendapatan yang digunakan untuk menabung.

Variabel tingkat bunga dalam penelitian ini tidak berpengaruh terhadap tingkat tabungan. Kenaikan tingkat bunga tidak mampu memberi rangsangan pada kenaikan tabungan masyarakat secara berarti. Hal ini karena tabungan masyarakat di Indonesia lebih dipengaruhi oleh GDP per kapita riil dan inflasi. Oleh karena itu untuk meningkatkan tabungan masyarakat tidak bisa dengan hanya menaikkan tingkat bunga tanpa didukung oleh tingkat pendapatan dan ekspektasi masyarakat.

\section{KESIMPULAN DAN SARAN}

\section{Kesimpulan}

Dari lima variabel bebas yang digunakan dalam model yang digunakan terdapat tiga variabel yang signifikan mempengaruhi tingkat tabungan masyarakat, yaitu GDP per kapita riil, inflasi dan variabel lag dari tingkat tabungan dan ketiganya memiliki pengaruh positif. Variabel GDP per kapita riil berpengaruh positif terhadap tingkat tabungan masyarakat. Dalam kasus di Indonesia kecenderungan peningkatan GDP per kapita riil berpengaruh pada dengan kenaikan tingkat tabungan selama periode penelitian. Kenaikan GDP per kapita riil berdampak pada peningkatan tingkat tabungan masyarakat. Dengan MPC tertentu, maka kenaikan GDP per kapita riil akan meningkatkan tabungan masyarakat.

Dalam penelitian ini variabel inflasi juga berpengaruh positif terhadap tingkat tabungan. Inflasi yang meningkat mengindikasikan meningkatknya ketidakpastian yang mendorong masyarakat untuk meningkatkan tabungan. Meskipun parameter dari perubahan tabungan akibat perubahan inflasi adalah kecil untuk di Indonesia, namun pengaruhnya sangat signifikan.

Variabel lag tingkat tabungan berpengaruh positif terhadap tingkat tabungan pada tahun tertentu. Hal ini menunjukkan adanya dorongan tingkat tabungan pada waktu sebelumnya terhadap tingkat tabungan sekarang yang berarti terdapat sifat inersia atau kelembaman pada tingkat tabungan dan mengimplikasikan bahwa tingkat tabungan masyarakat di Indonesia akan tetap meningkat di masa datang jika trend tingkat tabungan pada waktu sebelumnya cenderung meningkat.

Variabel angka beban ketergantungan tidak signifikan terhadap tingkat tabungan. Tingkat kesempatan kerja yang terbatas mencerminkan bahwa tidak semua penduduk umur produktif memperoleh pekerjaan dan pendapatan yang digunakan untuk menabung. 
Variabel tingkat bunga dalam penelitian ini tidak berpengaruh terhadap tingkat tabungan. Kenaikan tingkat bunga tidak mampu memberi rangsangan pada kenaikan tabungan masyarakat secara berarti. Hal ini karena tabungan masyarakat di Indonesia lebih dipengaruhi oleh GDP per kapita riil dan inflasi. Upaya untuk meningkatkan tabungan masyarakat tidak bisa dengan hanya menaikkan tingkat bunga tanpa didukung oleh tingkat pendapatan dan ekspektasi dari masyarakat.

Secara keseluruhan, ketiga variabel yang signifikan mempengaruhi tingkat tabungan di Indonesia di atas mendukung teori Keynes dan sejumlah studi empirik sebelumnya di antaranya Rossi (1988), Modigliani dan Cao (2004), Horioka dan Wan (2006). Sementara itu tidak signifikannya variabel yang merepresentasikan struktur penuduk juga sama dengan hasil temuan beberapa penelitian-penelitian sebelumnya seperti Kraay (200) dan Modigliani dan Cao (2004).

\section{Saran}

Berdasarkan hasil penelitian ini dapat diberikan beberapa saran bagi pengambil keputusan terutama pemerintah dan perbankan dalam upaya menghimpun dana dari masyarakat. Dalam upaya untuk meningkatkan tabungan masyarakat di masa datang maka kebijakan pemerintah yang dapat mendukung upaya tersebut adalah dengan melakukan kebijakan ekonomi makro dengan fokus dan sasaran yang diarahkan pada sasaran yang realistik yaitu peningkatan pendapatan per kapita masyarakat daripada sekedar kenaikan GDP tahunan. Peningkatan pendapatan per kapita tersebut dapat dilakukan dengan upaya peningkatan GDP yang optimal disertai dengan kebijakan pengendalian pertumbuhan penduduk melalui pengendalian tingkat kelahiran.

Pemerintah dan perbankan tidak dapat melakukan peningkatan tabungan masyarakat tanpa didukung oleh variabel penting yaitu tingkat pendapatan per kapita masyarakat. Jadi yang harus diperhatikan sekali lagi bahwa tingkat kesejahteraan masyarakat yang mestinya menjadi sasaran utama dalam kebijakan makro adalah faktor utama pendorong naiknya tingkat tabungan di dalam negeri.

\section{DAFTAR PUSTAKA}

Arrieta, G.M.G., 1988, "Interest Rates, Saving, and Growth in LDCs: An Assessment of Recent Empirical Research", World Development, Vol. 16.

Basri, Faisal, 2002, "Perekonomian Indonesia : Tantangan dan Harapan bagi Kebangkitan Indonesia", Penerbit Erlangga, Jakarta.

Bovenverg, A.L. dan Owen Evans, 1990, "National and Personal Saving in United States: Measurement and Analysis of Recent Trends". IMF Staff Paper. September, Vol. 37 No. 3.

Branson, W.H.danAlvin Klevorick, 1980, "Money Illusion and the Aggregate Consumption Function". American Economic Review. Vol. 59 (Desember).

Darmawan, Indra, 2006, "Perilaku Tabungan Masyarakat Antar Daerah di Indonesia" Universitas Sanata Dharma, Yogyakarta.

Deaton, Angus, 1977, "Involuntary Saving Through Unanticipated Inflation". American Economic Review. Vo. 67 (Desember).

Gujarati, Damodar dan Dawn C. Porter, 2009, "Basic Econometric", Fifth Edition, McGraw-Hill, inc, New York.

Gupta, K.L., 1987, “Aggregate Saving, Financial Intermediation, and Interest Rate". Review of Economics and Statistics. Mei, Vol. 69 No. 2. 
Horioka, Charles Yuji dan Junmin Wan, 2006, "The Determinants of Household Saving in China : A Dynamic Panel Analysis of Proficial Data", NBER Working Paper Series, Working Paper 12723 (Desember).

Howard, David H., 1978, "Personal Saving Behavior and the Rate of Inflation" Review of Economic and Statistics. Vol. 60 (November).

Keynes, John Maynard, 1953, "The General Theory of Employment, Interest, and Money", Harcourt Brace \& Company, New York.

Kraay, Aart, 2000, "Household Saving in China", World Bank Economic Review, vol. 14, no. 3 (September).

Lahiri, Ashok, 1989, "Dynamics of Asian Saving: The Role of Growth and Age Structure." IMF Staff Papers 36.

Leff, Nathaniel H., 1969, "Dependency Rates and Saving Rates". American Economic Review. No. 58.

Loayza, Noman, Klaus Schmidt-Hebbel, dan Luis Serven, 2000. "What Drives Private Saving Across the World?" Review of Economics and Statistics 82(2).

Meier, Gerald M. dan James E. Rauch, 2000, "Leading Issues in Economic Development", Seventh Edition, Oxford University Press, New York.

Modigliani, Franco, dan Shi Larry Cao, 2004,"The Chinese Saving Puzzle and the LifeCycle Hypothesis", Journal of Economic Literature, vol. 42, no. 1 (March).

Muradoglu, G. dan F. Taskin, 1996, "Differences in Household Saving Behaviour: Evidence from Industrial and Developing Countries". The Developing Economics. Juni, Vol. XXXIV, No. 2.
Ram, Rati, 1982, "Dependency Rates and Aggregate Savings: A New International Cross-Section Study" American Economic Review. No. 72.

Rossi, Nicola, 1988, “Government Spending, the Real Interest Rate, and the Behavior of Liquidity-Constrained Consumers in Developing Countries." IMF Staff Papers. Vol. 35 March.

Tambunan, Tulus, 2001, "Perekonomian Indonesia : Teori dan Temuan Empiris", Ghalia Indonesia, Jakarta.

Verbeek, Marno, 2000, “A Guide to Modern Econometrics", John Wiley \& Sons, Ltd., New York.

Word Bank, 1993, "The East Asia Miracle : Economic Growth and Public Policy", The East Asian Miracle, The Word Bank, Washington, D.C. 